Military Technical College Kobry El-Kobbah, Cairo, Egypt

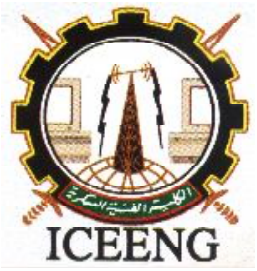

\author{
$10^{\text {th }}$ International Conference \\ on Electrical Engineering \\ ICEENG 2016
}

\title{
Smart Transmit abnormal Condition in High Voltage Substation by SCADA System between Protection Equipment's and National Control Center
}

\author{
By \\ Amer Nasr A. Elghaffar ${ }^{1}$, Karim M. Ibrahim² \\ Yehia Sayed M. Ali ${ }^{3}$, Adel A. Elbaset Mohamed ${ }^{4}$
}

\section{$\underline{\text { Abstract: }}$}

In high voltage substation it's important to fast simulate and analysis any fault or disturbed in the substation, SCADA system allow to faster analysis of real time and high resolution for the data which allows the operator to take faster decisions at any fault or abnormal condition in the substation.

This paper will discuss Supervisory Control and Data Acquisition (SCADA), where the accuracy meaning is a control system with applications in managing large-scale for industrial operations. The remote substation consists of protection and high voltage equipment that are directly interfaced to supervision center national control; fiber optical connection consists of high quality and fast transmitter data from the protection equipment by SCADA system, power system supervision and power Systems control all working in a coordinated automatic fashion. Data acquisition refers to collecting data in the form of measured analog current or voltages values or the Open or closed status of contact points. Power system supervision is carried out by Operators and maintenance engineers through this acquired data either at a remote site represented by computer displays and graphically wall displays or locally, at the Device site, in the form of frontpanel displays and laptop computers.

${ }^{1,2}$ Researchers, Electrical Engineering Department, Minia University, Cairo University

${ }^{3,4}$ Professor Electrical Engineering Department, Minia University, Minia, Egypt Dr.yehia60@yahoo.com, Dr_adel72@yahoo.com, Amernasr70@yahoo.com 


\section{Keywords:}

High voltage, Protection relay, SCADA and Fiber Optical

\section{Introduction:}

Supervisory Control and Data Acquisition (SCADA), in high voltage substation it's important to fast simulate and analysis any fault or disturbed in the substation, SCADA system allow to faster analysis of real time and high resolution for the data which allows the operator to take faster decisions at any fault or abnormal condition in the substation. Accuracy meaning is a control system with applications in managing large-scale for industrial operations.

The remote substation consists of protection and high voltage equipment that are directly interfaced to supervision center national control, fiber optical connection consists of high quality and fast for the transmit data from the protection equipment by SCADA system. Control room consists of computers which monitor, control real time data received from the remote station. Man power is required to monitor and control the real time data. Supervisory control and data acquisition is used to describe a system where both data acquisition and supervisory control are performed. Mobile Supervisory Control and Data Acquisition (referred to as Mobile SCADA) is the use of SCADA with the mobile phone network being used as the underlying communication medium. GSM is a wireless communication technology; most popular today for transmitting data anywhere in the world through SMS with the help of mobile phones in fig.1, Wireless SCADA deals with the creation of an inexpensive, yet adaptable and easy to use SCADA device and infrastructure using the mobile telephone network, in particular, the general Packet Radio Service (GPRS). The hardware components making up the device are relatively unsophisticated, yet the custom written software makes it reprogrammable over the air, and able to provide a given SCADA application with the ability to send and receive control and data signals at any non pre -determined time. 


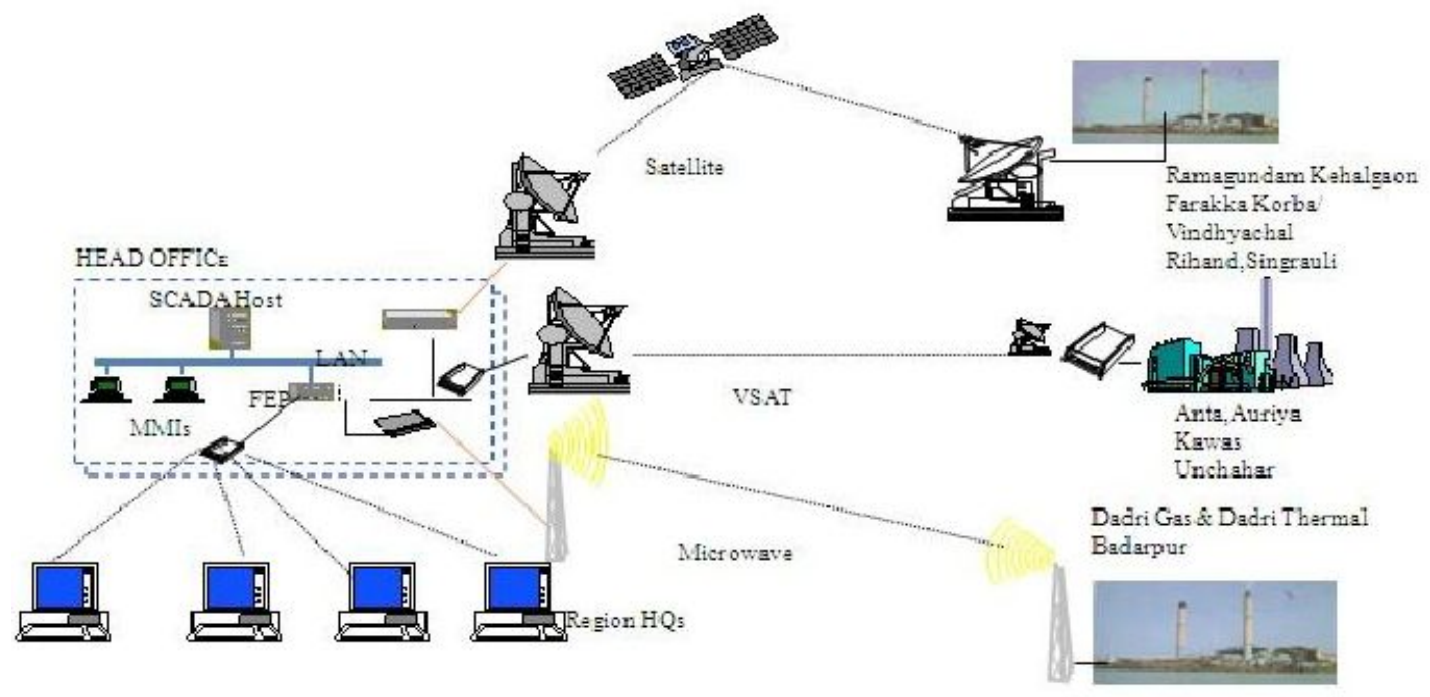

Figure (1): Smart SCADA system operation

\section{1. protective relay:}

A protective relay is the device, which operates to disconnect a faulty part of the system, thereby protecting the remainder of the system from further damage. In fact, power protection has the following five main functions as its levels of discipline and functionality

- to ensure safety of personnel

- to safeguard the entire system

- to ensure continuity of supply

- to minimize damage

- to reduce resultant repair costs

All of these requirements make its necessary to ensure relay detection, localization, and rapid isolation of electrical faults and additionally prompt and safe removal from service of faulty equipment. In order to satisfy the above requirements, protection must therefore have the following qualities.

- Reliability; to operate in the pre-determined manner when an electrical fault is detected.

- Selectivity, discrimination; To detect and safely isolate the faulty items.

- Stability / security; To leave all healthy circuits intact and undisturbed and to ensure continuity of supply

- Sensitivity; To detect even the smallest values of fault current or system abnormalities and operate correctly at its pre settings

- Speed; to operate speedily when it is required, thereby minimizing safety to personnel. 


\subsection{Abnormal of the Power System:}

Electrical faults usually occur because of the collapse of the insulating between the living conductor and the earth, it may be the cause of this insulating by any one or more of several factors, mechanical damage, high temperature, and voltage surges (caused by lighting or switch), the entry for an ionization the medium of air, medium and deterioration of insulation because of unfriendly environment or aging, or misuse of equipment. Fault current release an enormous amount of thermal energy, and if not quickly scan, may state fire hazards, and serious damage to the equipment and the risk to human life. Some of abnormal in power systems are; over voltage, over loads, unbalanced load, and flow of current transformer errors, short-circuit, short circuits with the ground, open connectors.

\subsection{Element of protection system in high voltage substations.:}

The relay receives information regarding the network mainly from the instrument transformers (voltage and current transformer), detects an abnormal condition by comparing this information to preset values, and gives a tripping command to the circuit breaker when such an abnormal condition has been detected. The relay may also be operated by an external tripping signal either from other instruments, from a SCADA master, or by human intervention, figure (2) discuss the operation of the protection system.

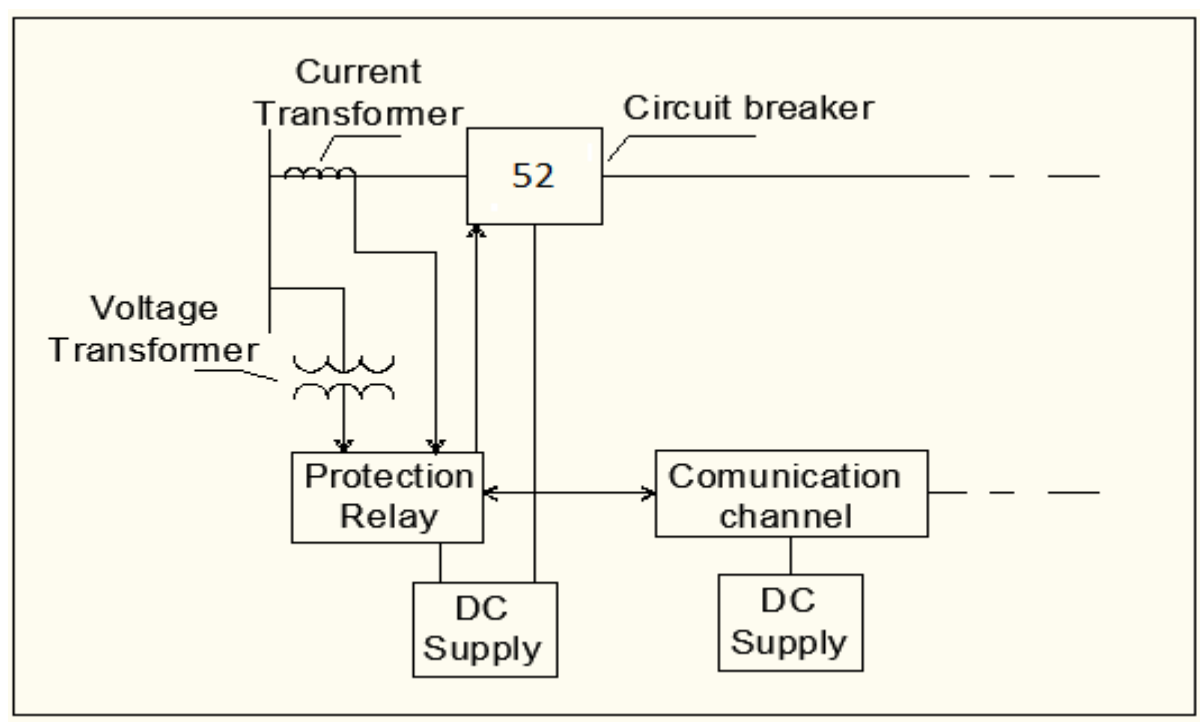

Figure (2): Elements of Protection System 


\section{SCADA System Communication to Protection Relay by Software Engineering:}

Remote Station consists of sensors and actuators that are directly interfaced to the generation plant or equipment's, the components present in a remote station are:

\subsection{Remote Terminal Unit (RTU):}

Remote Terminal unit acts as an interface between the field and the SCADA master It supports control and monitoring of digital and analog data.

The RTU panels consist of a power supply card and DO cards, processor, and memory communication card. The RTU panel is powered at $48 \mathrm{~V}$. The digital inputs are used to provide the status of switchyard equipment and station auxiliaries. The digital outputs are used for breaker and isolator commands and relay reset commands. There are also junction boxes which are present along with the equipment in order constantly.

\subsection{Bay Control Unit $(B C U)$ :}

It is a De-centralized architecture. It is an interface between the field and the SCADA master; it supports the control and monitoring of digital and analog data. BCU has memory unit, DI/DO modules, processor unit, communication unit, power supply unit.

\subsection{Gateway:}

The SCADA Gateway is a Windows application used by System Integrators and Utilities to collect data from OPC (Originating Point Codes), IEC(International Electro technical Commission) 60870-6 , IEC 61850, IEC 608705, DNP3, or Modbus Server/Slave devices and then supplies this data to other control systems supporting OPC. Gateways are used to interface with other systems.

The functions of gateway is to translate between protocol

\subsection{Multifunction Meter (MFM):}

It is an energy meter which communicates on MODBUS/TCP/IP. It gives various parameters like 3 phase voltages, currents. It requires less space and can replace conventional meters.

\subsection{Control Room:}

Control room consists of computers which monitor, control real time data received from the remote station, Man power is required to monitor and control the real time data. The components present in the control room are HMI that's apparatus which presents process data to a human operator, and through this, the human operator monitors and controls the process. 
A human-machine interface or HMI is the apparatus which presents process data to a human operator, and through which the human operator controls the process. An HMI is usually linked to the SCADA system's databases and software programs, to provide trending, diagnostic data, and management information such as scheduled maintenance procedures, logistic information, detailed schematics for a particular sensor or machine, and expert-system troubleshooting guides.

Protection relay two types input output module and protection relay, where some protection not available to connected by fiber direct with the communication unit, the same mechanical protection for the transformer or some type from differential relay (as the same relay 71k60000), in the figure (3) show how protection relay connected by fiber with the communication unit.

This unit transmits signals/data between the remote unit and the protection relay, this Communication mode connected with the protection relay by fiber optical connection, cable, figure (4) show communication units with the protection relay and the figure (6) show the fiber optical

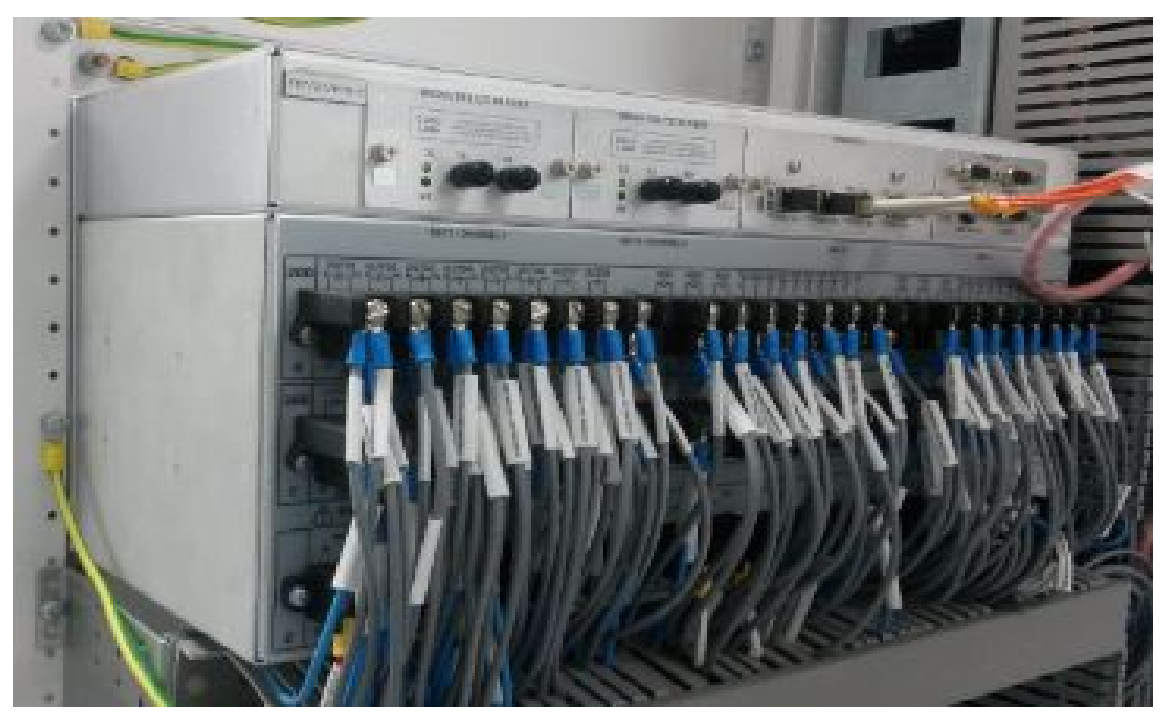

Figure (3): Protection relay connected by fiber with the communication unit 


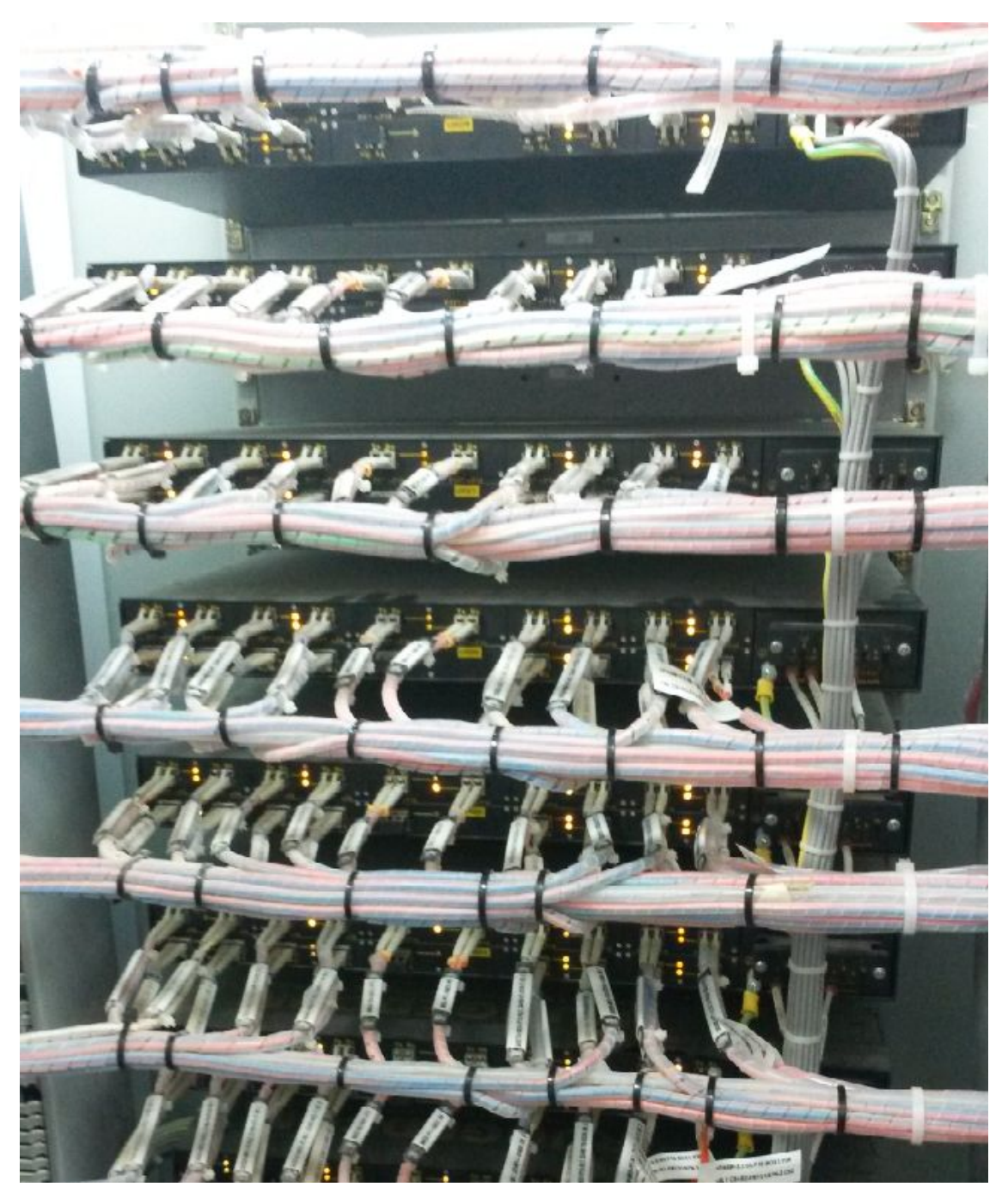

Figure (4): Communication units with protection relay

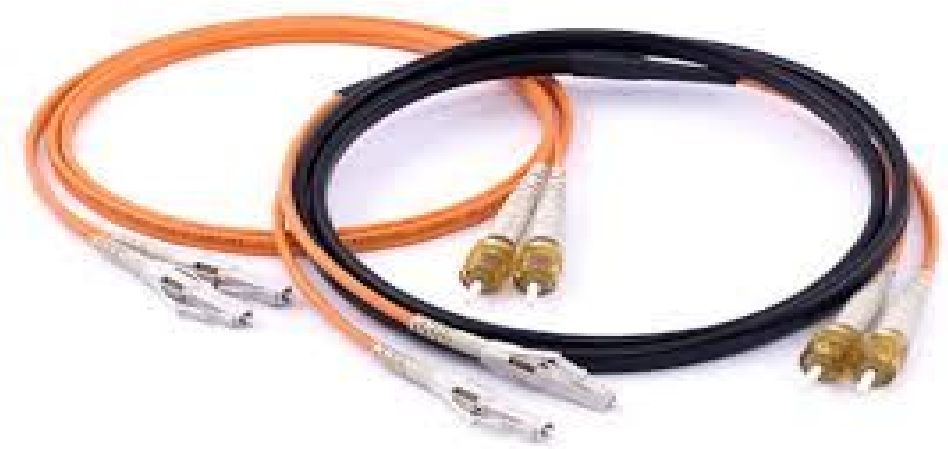

Figure (5): fiber optical cable

The software is an interface between the operator and the units. The processing software includes database and GIS (Geography Information System) the software gathers, 
process and transmit data to realize such functions:

A. Display the current operating situation of the feeder on Screen.

B. The fault detecting, locating, insulating and restoration in distribution systems.

The operator in the center monitors the operating situation of the feeder and also controls the switches in the feeder when a fault occurs. It allows the operator to visualize and control the functions of the process and use to modify for the final setting for protection relay, the engineering unit its available to send or receive with protective relay the program changed with the type for manufacturer the relay in the figure (6) discuss the actual connection to analysis fault with $\mathrm{ABB}$ protection over current relay for (REF 615), in figure (7a) showing actual three phases over current fault supervised by SEL411L protection relay. At the draft for this chapter will show and discuss the simple start to program protection relays different manufacture types and in figure (7b) show vector diagram.

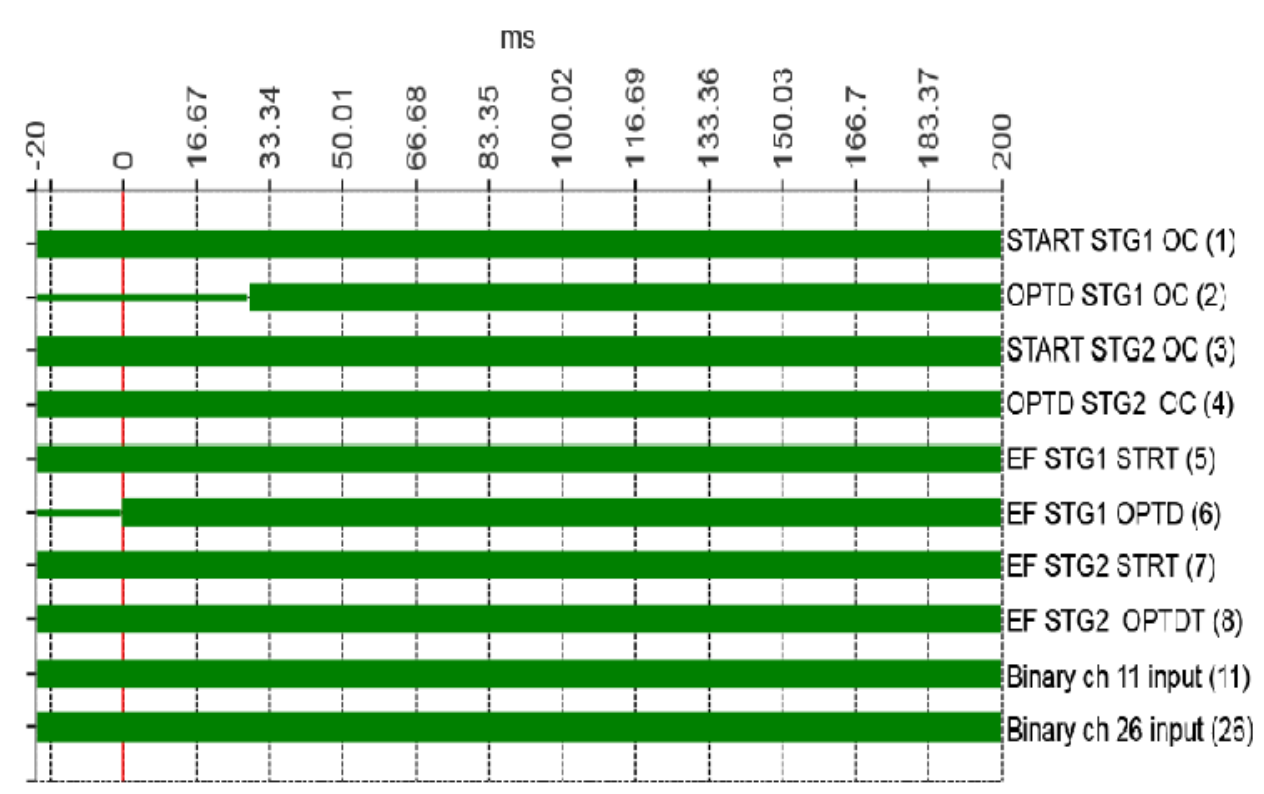

Figure (6): Actual connection with ABB protection over current relay for (REF 615) 

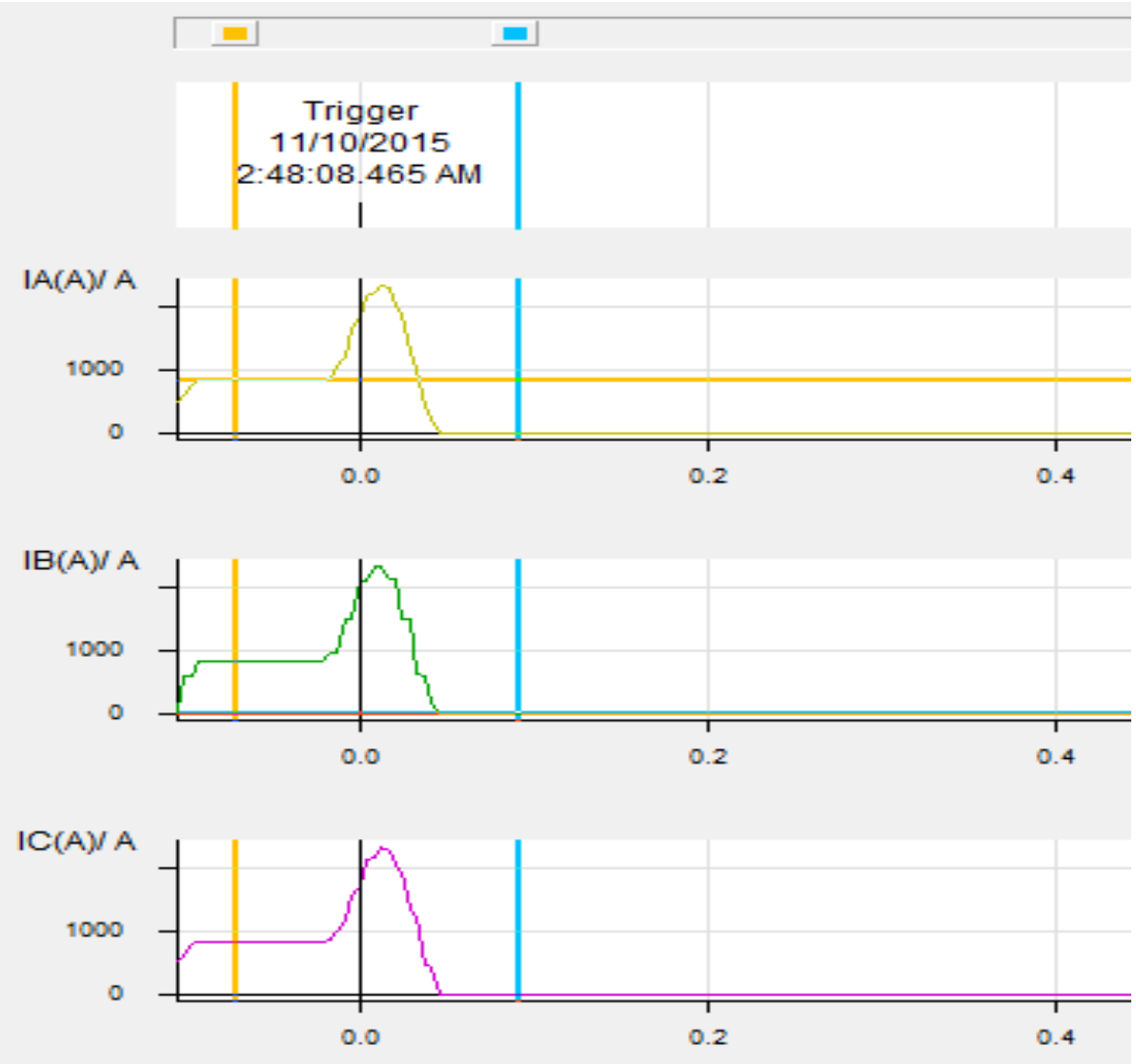

Figure (7a): Actual three phases over current fault by SELA11L Protection relay.
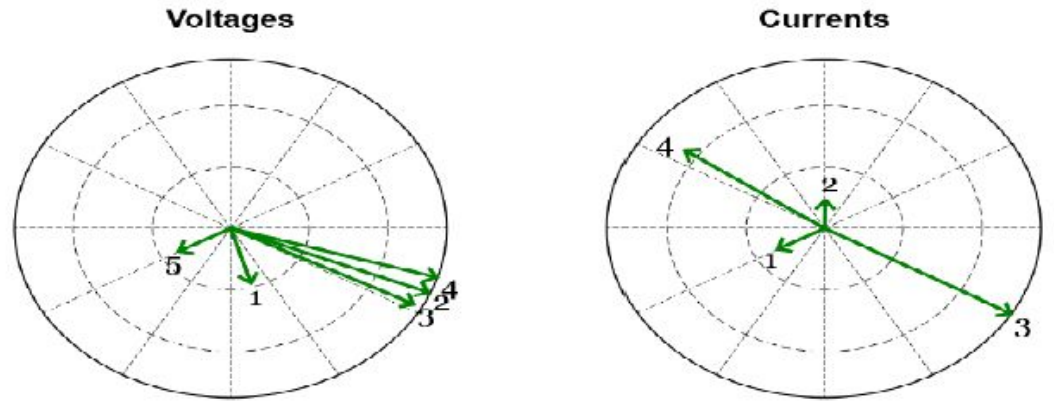

$\begin{array}{llllllll}\text { No. } & \text { Name } & \text { RMS } & \text { Angle } & \text { No. } & \text { Name } & \text { RMS } & \text { Angle } \\ 1 & \text { Uo } & 0.008(\mathrm{kV}) & 286.3^{\circ} & 1 & \text { IL1 } & 449.469(\mathrm{~A}) & 209.6^{\circ} \\ 2 & \text { U1 } & 0.024(\mathrm{kV}) & 3375^{\circ} & 2 & \text { IL2 } & 298.537(\mathrm{~A}) & 89.2^{\circ} \\ 3 & \text { U2 } & 0.023(\mathrm{kV}) & 332.1^{\circ} & 3 & \text { IL3 } & 1787.591(\mathrm{~A}) & 329.7^{\circ} \\ 4 & \text { U3 } & 0.024(\mathrm{kV}) & 343.1^{\circ} & 4 & 10 & 1420.991(\mathrm{~A}) & 144.4^{\circ} \\ 5 & \text { U1B } & 0007(\mathrm{kV}) & 2096^{\circ} & & & \end{array}$

Figure (7b): Vector diagram for over current fault ABB (REF615) protection relay

\section{Advantage of SCADA System:}

A. Reduced manpower. 
B. Time delay is reduced.

C. In control room it-self monitor the plant and. give commands through user.

D. Economical and safe operation.

E. Is there any modification and future extension, we can easily update in PLC \&SCADA. In substation, many switches are used, if there any one of the switch is trip means we can easily identify the particular area

\section{Power System Automation:}

A power system consists of devices that generate, transmit, and distribute power. Power system automation is the act of automatically controlling the power system via automated processes within computers and intelligent I\&C devices. It consists of three Major processes, namely, data acquisition, power system supervision and power Systems control all working in a coordinated automatic fashion. Data acquisition refers to collecting data in the form of measured analog current or voltages values or the Open or closed status of contact points. Power system supervision is carried out by Operators and maintenance engineers through this acquired data either at a remote site Represented by computer displays and graphically wall displays or locally, at the Device site, in the form of front-panel displays and laptop computers. Control refers to sending command messages to a device to operate I\&C (A collection of devices that monitor, control and protect the system is referred as instrumentation and control (I\&C) system) and power system devices.

\section{Monitoring System of Primary Values:}

The monitoring system is a real time supervision system of the field devices real time status (currents, voltages, pressures, temperatures, contacts, etc.). This supervision is made through digital equipment's and special sensors that are installed in the field devices of the substation. The data are collected and processed in a data acquisition and control unit (UAC), to thereafter through a communication network, using desirably a protocol standardized international sent to a central computer located at the control building of the substation and later to the operation centers and so allowing a remote supervision, in figure (8) and in the table (1) show actual metering current for line 132 KV where current transformer ratio (2000/1 A), table (2) show the metering voltage, the voltage transformer ratio ((132/sqrt (3) kv / 110 / sqr (3) V) and table (3) show metering for power by SCADA system. This function helps in arriving at the systems load patterns which helps in planning expansion. It also helps in detecting abnormal energy consumption patterns of the consumers and identifying high-loss areas. Processing the data obtained by the remote metering function and the data obtained from the substation does this. 


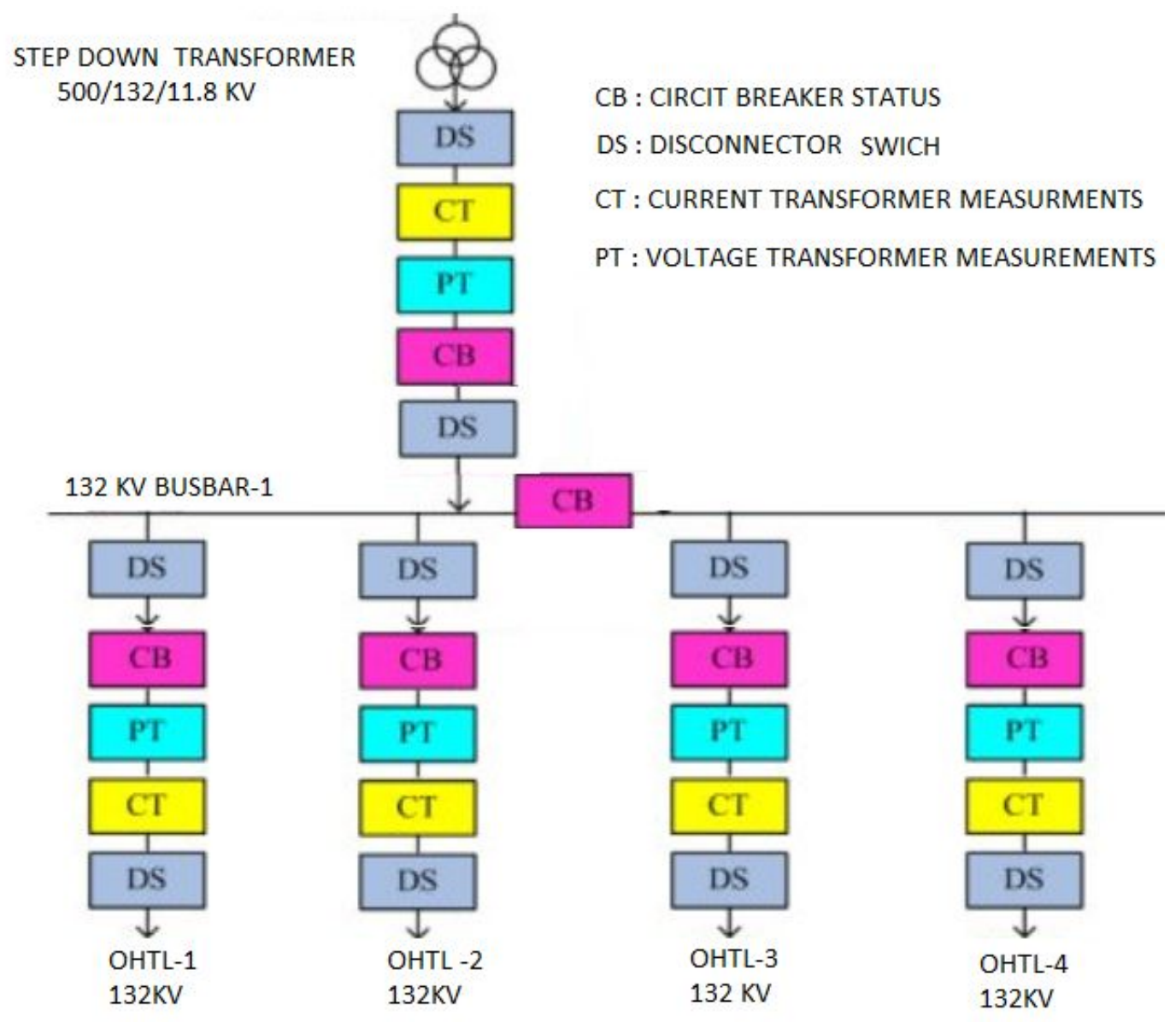

Figure (8): Metering by SCADA system.

Table (1): Actual metering current

\begin{tabular}{|c|c|c|c|c|c|c|c|c|}
\hline \multirow[t]{2}{*}{ QUA. } & \multirow{2}{*}{$\begin{array}{l}\text { INJECT } \\
\text { CUR. }\end{array}$} & \multirow{2}{*}{$\begin{array}{c}\text { EXPE. } \\
\text { VALUE } \\
\text { (KA) }\end{array}$} & \multicolumn{3}{|c|}{$\begin{array}{c}\text { MEASURED } \\
\text { VALUE(HMI) }\end{array}$} & \multicolumn{3}{|c|}{$\begin{array}{c}\text { MEASURED } \\
\text { VALUE(SCADA) }\end{array}$} \\
\hline & & & $\mathrm{R}$ & $\mathrm{Y}$ & B & $\mathrm{R}$ & $\mathrm{Y}$ & B \\
\hline \multirow{5}{*}{$\begin{array}{l}\text { PHASE } \\
\text { CURRENT } \\
\text { (A) }\end{array}$} & $25 \%$ & 500 & 497.7 & 497.5 & 498.6 & 497.6 & 497.7 & 498.4 \\
\hline & $50 \%$ & 1000 & 997.1 & 997.4 & 998.8 & 997.1 & 997.5 & 998.9 \\
\hline & $75 \%$ & 1500 & 1497.2 & 1498 & 1498.6 & 1497 & 1497.9 & 1498.7 \\
\hline & $100 \%$ & 2000 & 1996.5 & 1997.8 & 1998.8 & 1996.4 & 1997.7 & 1998.8 \\
\hline & $120 \%$ & 2400 & 2396.1 & 2396.7 & $2397 . .8$ & 2396 & 2397 & 2398 \\
\hline
\end{tabular}


Table (2): Actual metering voltage

\begin{tabular}{|c|c|c|c|c|c|c|c|c|}
\hline \multirow[t]{2}{*}{ QUA. } & \multirow{2}{*}{$\begin{array}{l}\text { INJE. } \\
\text { CUR. }\end{array}$} & \multirow{2}{*}{$\begin{array}{l}\text { EXPECTED } \\
\text { VALUE(KV) }\end{array}$} & \multicolumn{3}{|c|}{$\begin{array}{l}\text { MEASURED } \\
\text { VALUE (HMI) }\end{array}$} & \multicolumn{3}{|c|}{$\begin{array}{l}\text { MEASURED } \\
\text { VALUE(SCADA) }\end{array}$} \\
\hline & & & $\mathrm{R}$ & $Y$ & B & $\mathrm{R}$ & $Y$ & B \\
\hline \multirow{5}{*}{$\begin{array}{c}\text { LINE } \\
\text { VOLTAGE } \\
(\mathrm{KV})\end{array}$} & $25 \%=14.43$ & 27.5 & 27.5 & 27.5 & 27.5 & 27.5 & 27.5 & 27.5 \\
\hline & $50 \%=28.86$ & 55 & 55 & 55 & 55 & 55 & 55 & 55 \\
\hline & $75 \%=43.29$ & 82.5 & 82.5 & 82.5 & 82.5 & 82.5 & 82.5 & 82.5 \\
\hline & $100 \%=57.73$ & 110 & 110 & 110 & 110 & 110 & 110 & 110 \\
\hline & $120 \%=69.28$ & 132 & 132 & 132 & 132 & 132.1 & 132 & 132 \\
\hline
\end{tabular}

Table (3): Actual metering power

\begin{tabular}{|c|c|c|c|c|}
\hline MW & $\begin{array}{l}\text { INJECTED } \\
\text { VOLTAGE }\end{array}$ & $\begin{array}{c}\text { EXP. } \\
\text { VALUE(KV) }\end{array}$ & $\begin{array}{l}\text { ACTUAL } \\
\text { VALUE } \\
\text { (BCU) }\end{array}$ & $\begin{array}{c}\text { ACTUAL } \\
\text { VALUE(HMI) }\end{array}$ \\
\hline \multirow{5}{*}{$\begin{array}{c}\text { RYB } \\
\text { ANGLE } \\
\text { BETWEEN } \\
\text { VOLTAGE } \\
\text { AND } \\
\text { CURRENT } \\
\Phi=0\end{array}$} & $\begin{array}{l}\mathrm{I}=0.25 \mathrm{~A} \\
\mathrm{~V}=57.74 \mathrm{~V}\end{array}$ & $95.262 \mathrm{MW}$ & 94.81 & 94.8 \\
\hline & $\begin{array}{c}\mathrm{I}=0.5 \mathrm{~A} \\
\mathrm{~V}=57.74 \mathrm{~V}\end{array}$ & $190.525 \mathrm{MW}$ & 189.98 & 190 \\
\hline & $\begin{array}{l}\mathrm{I}=0.75 \mathrm{~A} \\
\mathrm{~V}=57.74 \mathrm{~V}\end{array}$ & 285.788 MW & 285.3 & 285.3 \\
\hline & $\begin{array}{c}\mathrm{I}=1 \mathrm{~A} \\
\mathrm{~V}=57.74 \mathrm{~V}\end{array}$ & 381.05 MW & 380.48 & 381.6 \\
\hline & $\begin{array}{c}\mathrm{I}=1.2 \mathrm{~A} \\
\mathrm{~V}=57.74 \mathrm{~V}\end{array}$ & 457.26 MW & 456.52 & 456.1 \\
\hline \multirow{5}{*}{$\begin{array}{c}\text { RYB } \\
\text { ANGLE } \\
\text { BETWEEN } \\
\text { VOLTAGE } \\
\text { AND } \\
\text { CURRENT } \\
\Phi=180\end{array}$} & $\begin{array}{l}\mathrm{I}=0.25 \mathrm{~A} \\
\mathrm{~V}=57.74 \mathrm{~V}\end{array}$ & $-95.262 \mathrm{MW}$ & -94.83 & -94.1 \\
\hline & $\begin{array}{c}\mathrm{I}=0.5 \mathrm{~A} \\
\mathrm{~V}=57.74 \mathrm{~V}\end{array}$ & $\begin{array}{c}-190.525 \\
\text { MW }\end{array}$ & -190.07 & --190.1 \\
\hline & $\begin{array}{l}\mathrm{I}=0.75 \mathrm{~A} \\
\mathrm{~V}=57.74 \mathrm{~V}\end{array}$ & $\begin{array}{c}-285.788 \\
\text { MW }\end{array}$ & -285.81 & -285.3 \\
\hline & $\begin{array}{c}\mathrm{I}=1 \mathrm{~A} \\
\mathrm{~V}=57.74 \mathrm{~V}\end{array}$ & $-381.05 \mathrm{MW}$ & -380.51 & -381.6 \\
\hline & $\begin{array}{c}\mathrm{I}=1.2 \mathrm{~A} \\
\mathrm{~V}=57.74 \mathrm{~V}\end{array}$ & $-457.26 \mathrm{MW}$ & -456.56 & -455.4 \\
\hline
\end{tabular}




\section{SCADA For Supervision by Transmission Data :}

The analog input card is collected the analog data like Load current, Voltage, Reactive power, Real power and Frequency. The digital input card is collected the digital data like status of circuit breaker and isolator. .In RTU this analog and digital signal is converted into a digital form by protocol. In table (4) showing the commands to the circuit breaker and dis-connector switch which order send by SCADA by two click for the equipment needing to operate from single line diagram in the central control, this order will give souring from the command that the request need to give (YES) or (NO), the selection ( ok ) will send the serial password for this substation the central main unit will send this serial to operation relay which close the contact synchronies with the serial number in the BCU relay which give the order for this contact wiring with the line.

The status from the circuit breaker, dis-connector switch and earth switch from the substation are send by serial password to control central by 1 or 0 by SCADA the status for line $132 \mathrm{KV}$ shown in the table (5).

Table (4): Rule base for the position controller

\begin{tabular}{|c|c|c|c|c|c|c|c|c|}
\hline \multirow[b]{2}{*}{$\begin{array}{l}\text { Sr. } \\
\text { no }\end{array}$} & \multicolumn{2}{|c|}{ LCC } & \multicolumn{2}{|l|}{ HMI } & \multicolumn{2}{|c|}{$\begin{array}{c}\text { SOE1, } \\
\text { SOE2 } \\
\text { MASTERS }\end{array}$} & \multicolumn{2}{|c|}{ SCADA MASTER } \\
\hline & SOURCE & $\mathrm{BCU}$ & SAS TEXT & 安岁 & 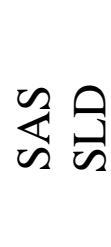 & 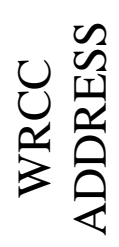 & 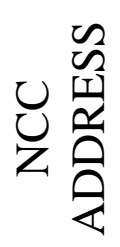 & $\begin{array}{c}\text { SCADA } \\
\text { TEXT }\end{array}$ \\
\hline 1 & $\begin{array}{l}\text { Q0 } \\
\text { EGY-1 } \\
\text { OPEN }\end{array}$ & $\begin{array}{c}\text { OPE } \\
\mathrm{N}\end{array}$ & $\begin{array}{l}\text { CIRCUIT } \\
\text { BREAKER } \\
\text { Q0 OPEN }\end{array}$ & $\begin{array}{c}\text { OPE } \\
\mathrm{N}\end{array}$ & $\begin{array}{c}\mathrm{OPE} \\
\mathrm{N}\end{array}$ & \multirow[t]{2}{*}{2030} & \multirow[t]{2}{*}{2030} & $\begin{array}{c}\text { EGY-1 } \\
\text { CIRCUIT } \\
\text { BREAKER } \\
\text { Q0 }\end{array}$ \\
\hline 2 & $\begin{array}{c}\text { Q0 } \\
\text { EGY-1 } \\
\text { CLOSE }\end{array}$ & $\begin{array}{c}\text { CLO } \\
\text { SE }\end{array}$ & $\begin{array}{l}\text { CIRCUIT } \\
\text { BREAKER } \\
\text { Q0 CLOSE }\end{array}$ & $\begin{array}{l}\text { CLO } \\
\text { SE }\end{array}$ & $\begin{array}{c}\text { CLO } \\
\text { SE }\end{array}$ & & & $\begin{array}{c}\text { EGY-1 } \\
\text { CIRCUIT } \\
\text { BREAKER } \\
\text { Q0 }\end{array}$ \\
\hline 3 & $\begin{array}{c}\text { Q1 } \\
\text { EGY-1 } \\
\text { OPEN }\end{array}$ & $\begin{array}{c}\text { OPE } \\
\mathrm{N}\end{array}$ & $\begin{array}{c}\text { BUSBAR } \\
\text { DISCONN } \\
\text { ECTOR Q1 } \\
\text { OPEN }\end{array}$ & $\begin{array}{c}\text { OPE } \\
\mathrm{N}\end{array}$ & $\begin{array}{c}\text { OPE } \\
\mathrm{N}\end{array}$ & 2031 & 2031 & $\begin{array}{c}\text { EGY-1 BB } \\
\text { DISCONNE } \\
\text { CTOR Q1 }\end{array}$ \\
\hline
\end{tabular}




\begin{tabular}{|c|c|c|c|c|c|c|c|c|}
\hline 4 & $\begin{array}{c}\text { Q1 } \\
\text { EGY-1 } \\
\text { CLOSE }\end{array}$ & $\begin{array}{c}\text { CLO } \\
\text { SE }\end{array}$ & $\begin{array}{c}\text { BUSBAR } \\
\text { DISCONN } \\
\text { ECTOR } \\
\text { Q1CLOSE }\end{array}$ & $\begin{array}{c}\text { CLO } \\
\text { SE }\end{array}$ & $\begin{array}{c}\text { CLO } \\
\text { SE }\end{array}$ & & & $\begin{array}{c}\text { EGY-1 BB } \\
\text { DISCONNE } \\
\text { CTOR Q1 }\end{array}$ \\
\hline 5 & $\begin{array}{c}\text { Q51 } \\
\text { EGY-1 } \\
\text { OPEN }\end{array}$ & $\begin{array}{c}\text { OPE } \\
\mathrm{N}\end{array}$ & $\begin{array}{l}\text { MAINTEN } \\
\text { ANCE } \\
\text { EARTHIN } \\
\text { G SWITCH } \\
\text { Q51 OPEN }\end{array}$ & $\begin{array}{c}\text { OPE } \\
\mathrm{N}\end{array}$ & $\begin{array}{c}\text { OPE } \\
\mathrm{N}\end{array}$ & \multirow[t]{2}{*}{2032} & \multirow[t]{2}{*}{2032} & $\begin{array}{c}\text { AD05 } \\
\text { MAINTENA } \\
\text { NCE ES Q51 }\end{array}$ \\
\hline 6 & $\begin{array}{c}\text { Q51 } \\
\text { EGY-1 } \\
\text { CLOSE }\end{array}$ & $\begin{array}{c}\text { CLO } \\
\text { SE }\end{array}$ & $\begin{array}{l}\text { MAINTEN } \\
\text { ANCE } \\
\text { EARTHIN } \\
\text { G SWITCH } \\
\text { Q51CLOSE }\end{array}$ & $\begin{array}{c}\text { CLO } \\
\text { SE }\end{array}$ & $\begin{array}{c}\text { CLO } \\
\text { SE }\end{array}$ & & & $\begin{array}{c}\text { EGY-1 } \\
\text { MAINTENA } \\
\text { NCE ES Q51 }\end{array}$ \\
\hline 7 & $\begin{array}{c}\text { Q2 } \\
\text { EGY-1 } \\
\text { OPEN }\end{array}$ & $\begin{array}{c}\text { OPE } \\
\mathrm{N}\end{array}$ & $\begin{array}{c}\text { BUSBAR } \\
\text { DISCONN } \\
\text { ECTOR Q2 } \\
\text { OPEN }\end{array}$ & $\begin{array}{c}\text { OPE } \\
\mathrm{N}\end{array}$ & $\begin{array}{c}\text { OPE } \\
\mathrm{N}\end{array}$ & \multirow{2}{*}{2033} & \multirow{2}{*}{2033} & $\begin{array}{c}\text { EGY-1 BB } \\
\text { DISCONNE } \\
\text { CTOR Q2 }\end{array}$ \\
\hline 8 & $\begin{array}{c}\text { Q2 } \\
\text { EGY-1 } \\
\text { CLOSE }\end{array}$ & $\begin{array}{c}\text { CLO } \\
\text { SE }\end{array}$ & $\begin{array}{c}\text { BUSBAR } \\
\text { DISCONN } \\
\text { ECTOR Q2 } \\
\text { CLSE } \\
\end{array}$ & $\begin{array}{c}\text { CLO } \\
\text { SE }\end{array}$ & $\begin{array}{c}\text { CLO } \\
\text { SE }\end{array}$ & & & $\begin{array}{l}\text { EGY-1 BB } \\
\text { DISCONNE } \\
\text { CTOR Q2 }\end{array}$ \\
\hline
\end{tabular}

In high voltage substations at any abnormal condition the data transmit from substation to national control center by SCADA system where protection relay send the serial password to channel in collection data(RTU) serial from relay are configure in the central unit by another password to send to control center, in another hand the tow password are programed to text this text by function operated in protection relay, in tables (6) and table (7) are simulate example for transmit by SCADA to control central, where table (6) discuss protection relay used with transformer protection and table (7) used for Over-head transmission line that send the condition by serial that's translate to text in the central control in the substation and at limited for SCADA serial number that's can be collect some protection in one serial that translate in the national control center to text, as the same all temperature protection collected in one serial, all zones distance in one serial ,....etc. 
Table (5): Protection relay for power transformer send the abnormal condition

\begin{tabular}{|c|c|c|c|c|c|}
\hline \multirow[b]{2}{*}{$\begin{array}{l}\mathrm{Sr} \\
\text { no }\end{array}$} & \multirow[b]{2}{*}{ SOURCE } & \multicolumn{2}{|c|}{ SOE1 ,SOE2 MASTERS } & \multicolumn{2}{|c|}{ SCADA MASTER } \\
\hline & & SOE, HMI (SAS TEXT) & 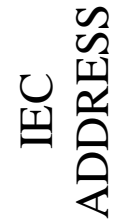 & 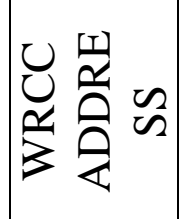 & $\begin{array}{c}\text { SCADA } \\
\text { TEXT }\end{array}$ \\
\hline 1 & $\begin{array}{c}\text { TRANS.1 - } \\
132 \mathrm{KV}\end{array}$ & $\begin{array}{l}\text { TRANS. } 1-132 \mathrm{KV}- \\
\text { MAIN TANK OIL } \\
\text { TEMP HIGH TRIP }\end{array}$ & 5031 & \multirow{4}{*}{1015} & \multirow{4}{*}{$\begin{array}{l}\text { TRANS.1- } \\
\text { 132KV } \\
\text { TEMP. } \\
\text { TRIP }\end{array}$} \\
\hline 2 & $\begin{array}{c}\text { TRANS.1 - } \\
132 \mathrm{KV}\end{array}$ & $\begin{array}{l}\text { TRANS. } 1-132 \mathrm{KV}- \\
\text { MAIN TANK OIL } \\
\text { LEVEL LOW TRIP }\end{array}$ & 5032 & & \\
\hline 3 & $\begin{array}{c}\text { TRANS.1 - } \\
132 \mathrm{KV}\end{array}$ & $\begin{array}{l}\text { TRANS. } 1 \text { - 132KV - } \\
\text { OLTC OIL LEVEL } \\
\text { LOW TRIP }\end{array}$ & 5033 & & \\
\hline 4 & $\begin{array}{l}\text { TRANS.1 - } \\
\text { 132KV }\end{array}$ & $\begin{array}{l}\text { TRANS. } 1-132 \mathrm{KV}- \\
\text { MAIN TANK OIL } \\
\text { TEMP HIGH ALARM }\end{array}$ & 5034 & & \\
\hline 5 & $\begin{array}{c}\text { TRANS.1 - } \\
132 \mathrm{KV}\end{array}$ & $\begin{array}{c}\text { TRANS. } 1-132 \mathrm{KV}- \\
\text { MAIN TANK } \\
\text { BOCHLOZ TRIP }\end{array}$ & 5035 & \multirow{3}{*}{1016} & \multirow{3}{*}{$\begin{array}{l}\text { TRANS.1- } \\
\text { 132KV } \\
\text { BUCHZ. } \\
\text { TRIP }\end{array}$} \\
\hline 6 & $\begin{array}{l}\text { TRANS.1 - } \\
\text { 132KV }\end{array}$ & $\begin{array}{l}\text { TRANS. } 1-132 \mathrm{KV}- \\
\text { TAP CHANGER } \\
\text { BUCHLOZ TRIP }\end{array}$ & 5036 & & \\
\hline 7 & $\begin{array}{c}\text { TRANS.1 - } \\
\text { 132KV }\end{array}$ & $\begin{array}{l}\text { TRANS. } 1 \text { - 132KV - } \\
\text { PREESURE RELIEF } \\
\text { TRIP }\end{array}$ & 5037 & & \\
\hline 8 & $\begin{array}{l}\text { TRANS.1 - } \\
\text { 132KV }\end{array}$ & $\begin{array}{c}\text { TRANS. } 1-132 \mathrm{KV}- \\
\text { MAIN TANK OIL } \\
\text { LEVEL HIGH ALARM }\end{array}$ & 5038 & \multirow{2}{*}{1017} & \multirow{2}{*}{$\begin{array}{l}\text { TRANS.1 } \\
\text { OIL TEMP } \\
\text { ALARM }\end{array}$} \\
\hline 9 & $\begin{array}{c}\text { TRANS.1 - } \\
132 \mathrm{KV}\end{array}$ & $\begin{array}{l}\text { TRANS. } 1 \text { - 132KV - } \\
\text { OLTC OIL LEVEL } \\
\text { HIGH ALARM }\end{array}$ & 5039 & & \\
\hline 10 & $\begin{array}{c}\text { TRANS.1 - } \\
132 \mathrm{KV}\end{array}$ & $\begin{array}{l}\text { TRANS. } 1 \text { - 132KV - } \\
\text { SET - } 1 \text { DIFF PROT } \\
\text { PH-A OPTD }\end{array}$ & 5040 & \multirow[t]{2}{*}{1018} & \multirow[t]{2}{*}{$\begin{array}{c}\text { TRANS.1 } \\
\text { PROT.TRIP }\end{array}$} \\
\hline 11 & TRANS.1 - & TRANS.1 - 132KV - & 5041 & & \\
\hline
\end{tabular}




\begin{tabular}{|c|c|c|c|}
\hline & & PH-B OPTD & \\
\hline 12 & $\begin{array}{c}\text { TRANS.1 - } \\
132 \mathrm{KV}\end{array}$ & $\begin{array}{c}\text { TRANS. } 1 \text { - 132KV - } \\
\text { SET - } 1 \text { DIFF PROT } \\
\text { PH-C OPTD }\end{array}$ & 5042 \\
\hline 13 & $\begin{array}{l}\text { TRANS.1 - } \\
\text { 132KV }\end{array}$ & $\begin{array}{c}\text { TRANS. } 1-132 \mathrm{KV}- \\
\text { SET - } 1 \text { 87REF/T OPTD }\end{array}$ & 5043 \\
\hline
\end{tabular}

Table (6): Protection relay for over-head transmission line send the abnormal condition

\begin{tabular}{|c|c|c|c|c|c|}
\hline \multirow[b]{2}{*}{$\begin{array}{l}\text { Sr. } \\
\text { no }\end{array}$} & \multirow{2}{*}{$\begin{array}{l}\text { PANEL } \\
\text { SOURCE }\end{array}$} & \multicolumn{2}{|c|}{ SOE1 ,SOE2 MASTERS } & \multicolumn{2}{|c|}{ SCADA MASTER } \\
\hline & & SOE , HMI (SAS TEXT) & 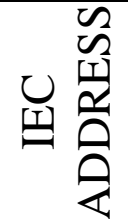 & 亚 & SCADA TEXT \\
\hline 1 & $\begin{array}{l}\text { P. REL. } \\
\text { MAIN-1 }\end{array}$ & $\begin{array}{c}\text { ASSUIT-1 - OHL - } \\
\text { 500KV - O/C PROT L1 } \\
\text { OPTD }\end{array}$ & 9014 & \multirow{4}{*}{1306} & \multirow{4}{*}{$\begin{array}{c}\text { ASSUIT -1 } \\
\text { O/C-E/F } \\
\text { PROT. OPTD }\end{array}$} \\
\hline 2 & $\begin{array}{l}\text { P. REL. } \\
\text { MAIN-1 }\end{array}$ & $\begin{array}{c}\text { ASSUIT-1 - OHL - } \\
500 \mathrm{KV} \mathrm{-} \mathrm{O/C} \mathrm{PROT} \mathrm{L2} \\
\text { OPTD }\end{array}$ & 9015 & & \\
\hline 3 & $\begin{array}{l}\text { P. REL. } \\
\text { MAIN-1 }\end{array}$ & $\begin{array}{l}\text { ASSUIT-1 - OHL - } \\
\text { 500KV - O/C PROT L3 } \\
\text { OPTD }\end{array}$ & 9016 & & \\
\hline 4 & $\begin{array}{l}\text { P. REL. } \\
\text { MAIN-1 }\end{array}$ & $\begin{array}{c}\text { ASSUIT-1 - OHL - } \\
500 \mathrm{KV} \text { - E/F PROT TRIP }\end{array}$ & 9017 & & \\
\hline 5 & $\begin{array}{l}\text { P. REL. } \\
\text { MAIN-1 }\end{array}$ & $\begin{array}{c}\text { ASSUIT-1 - OHL - } \\
\text { 500KV - } 21 \text { DIST PROT } \\
\text { ZONE-1 OPTD }\end{array}$ & 9018 & \multirow[t]{4}{*}{1307} & \multirow[t]{4}{*}{$\begin{array}{l}\text { ASSUIT -1 } \\
\text { DIST PROT. } \\
\text { OPTD }\end{array}$} \\
\hline 6 & $\begin{array}{l}\text { P. REL. } \\
\text { MAIN-1 }\end{array}$ & $\begin{array}{c}\text { ASSUIT-1 - OHL - } \\
\text { 500KV - } 21 \text { DIST PROT } \\
\text { ZONE-2 OPTD }\end{array}$ & 9019 & & \\
\hline 7 & $\begin{array}{l}\text { P. REL. } \\
\text { MAIN-1 }\end{array}$ & $\begin{array}{c}\text { ASSUIT-1 - OHL - } \\
\text { 500KV - } 21 \text { DIST PROT } \\
\text { ZONE-3 OPTD }\end{array}$ & 9020 & & \\
\hline 8 & $\begin{array}{l}\text { P. REL. } \\
\text { MAIN-1 }\end{array}$ & $\begin{array}{c}\text { ASSUIT-1 - OHL - } \\
\text { 500KV - 21 DIST PROT } \\
\text { ZONE-4 OPTD }\end{array}$ & 9021 & & \\
\hline
\end{tabular}




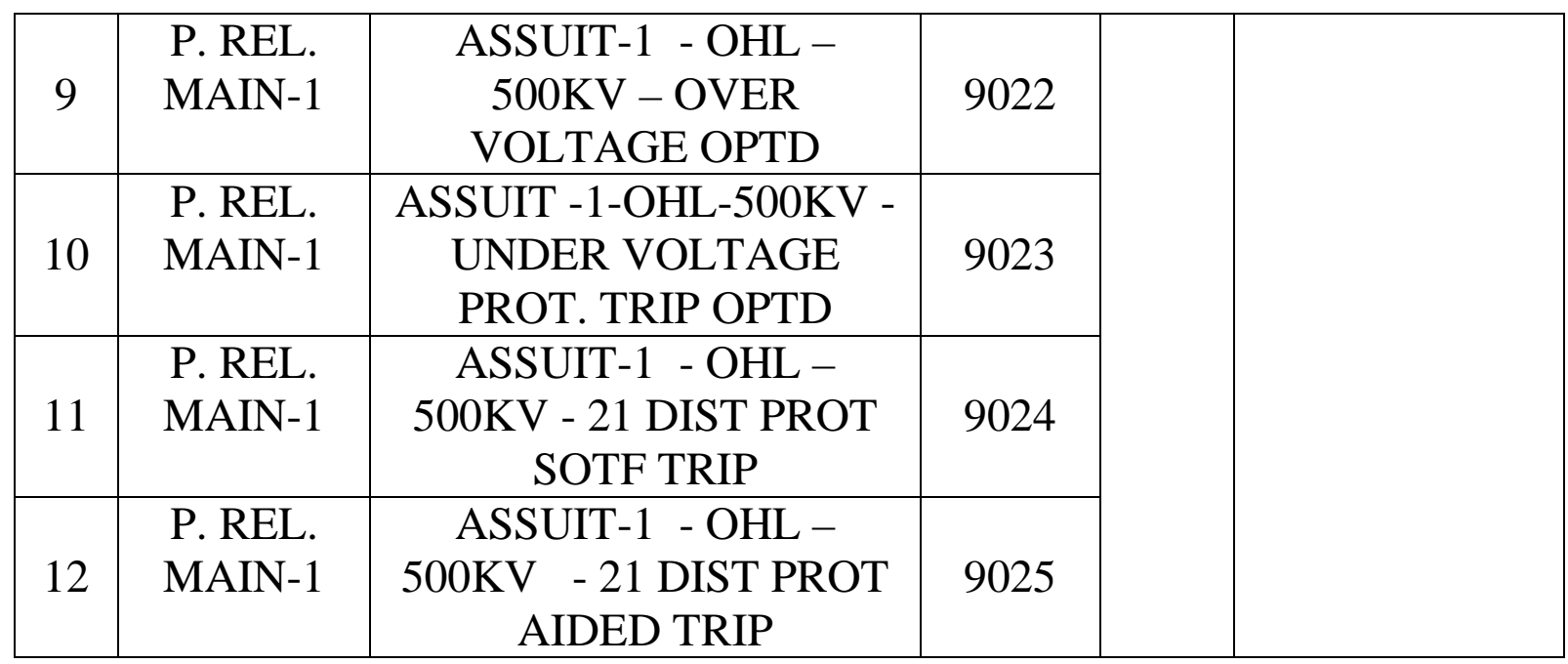

\section{Conclusions:}

This paper presents, what is the need of SCADA in the present high voltage substations, the SCADA system is used for monitoring and controlling power industry from national central control. its presented the importance of SCADA and the integration of Hardware and Software components to the power industry SCADA system is that one which interested in collecting data from field using different devices such as $\mathrm{ABB}$ protection Relay and SEL411L protection relay, SCADA provides management with real-time data on production operations; an implement more efficient control paradigms, improve plant and personnel safety, and reduces costs of man power for operation. The security of SCADA systems depends on the effective application of security principles and technology to the SCADA system. The quality and quantity of the product will be enhanced accordingly using SCADA system.

SCADA system is a real time system in which the information is time stamped along with the event SCADA system provides faster analysis of real time data which allows the operator to make faster decisions with the help of different alarms on the panels. SCADA systems reduces human error (that occurs while taking readings mostly) making the system more efficient and reliable. It keeps a record of the data and analysis of the past years which can be easily accessed.

\section{References:}

[1] J. Lewis Blackburn and Thomas J. Domin "Protective Relaying "Principles and Applications "Third Edition (2006), ISBN10: 1-57444-716-5

[2] ABB - Protection Application Handbook, BA THS/BU Transmission Systems and Substations ABB Transmission and Distribution Management Ltd book no (6), BA 
THS / BU Transmission Systems and Substations, P. O. Box 8131, CH - 8050 Zürich Switzerland

[3] Mohamed Najeh Lakhoua, Mohamed Kamel Jbira "Project Management Phases of a SCADA System for Automation of Electrical Distribution Networks" IJCSI International Journal of Computer Science IssuesVol. 9, Issue 2, No 2, March 2012, ISSN (Online): 1694-0814

[4] A.Merlin Sharmila, S.Savitha Raj “ A Smart Distribution Automation using Supervisory Control and Data Acquisition with Advanced Metering Infrastructure and GPRS Technology" International Journal of Engineering Research and General Science Volume 2, Issue 5, August-September, 2014, ISSN 2091-2730

[5] Sungjin Lee, Donghyun Choi, Choonsik Park, and Seungjoo Kim "An Efficient Key Management Scheme for Secure SCADA Communication" International Journal of Computer, Electrical, Automation, Control and Information Engineering Vol:2, No:9, 2008, Publication/15268

[6] T.Vignesh1, J.Kirubakaran2 "Automation based power transmission control Station using PLC and SCADA" IJISET - International Journal of Innovative Science, Engineering \& Technology, Vol. 2 Issue 2, February 2015, ISSN 2348 7968

[7] R. Kirubashankar, K. Krishnamurthy, J. Indra, B.Vignesh "Design and Implementation of Web Based Remote Supervisory Control and Information System" International Journal of Soft Computing and Engineering (IJSCE), Volume-1, Issue-4, September 2011, ISSN: 2231-2307

[8] Aye Min Zaw, Hla Myo Tun "Design and Implementation of SCADA System Based Power Distribution for Primary Substation ( Monitoring System)" International Journal of Science, Engineering and Technology Research (IJSETR), Volume 3, Issue 5, May 2014, ISSN: $2278-7798$

[9] R. Logeswaran, R. Selvamanikandan, N. Subramanian, G. Jothi Priya "Implementation of SCADA at Mylapore Substation" International Journal of Innovative Research in Science, Engineering and Technology, Volume 4, Special Issue 2, February 2015, ISSN (Online) : $2319-8753$

[10] Mehdi J. Marie, Ghaida A. AL-Suhail, Hussein T. Kadhim "Developing Al-Najaf Cement Plant using Wireless SCADA System" International Journal of Computer Applications (0975 - 8887) Volume 64- No.13, February 2013

[11] Parth DesaiÄ, Sharyu Mahale, Pooja Desai and Sunil Karamchnadani " Smart SCADA and Automation System in Power Plants" International Journal of Current Engineering and Technology, Vol.4, No.5 Oct 2014, P-ISSN 2347 - 5161

[12] Hari Kumar Naidu and K.Thanushkodi “ The Era of Global Standard for SCADA Substation Automation" International Journal of Electronic Engineering Research ISSN 0975 - 6450 Volume 1 Number 3 (2009) pp. 245-257 
[13] U. S. Patil "Study of Wireless Sensor Network in SCADA System for Power Plant" International Journal of Smart Sensors and Ad Hoc Networks (IJSSAN) (Print) Volume-1, Issue-2, 2011, ISSN No. 2248-9738

[14] International Journal of Electronics and Computer Science Engineering " Design and Implementation of SCADA System Based Power Distribution for Primary Substation (Control System)" ISSN- 2277-1956

[15] Shabnam Rukhsar "SCADA in Transmission Line" IOSR Journal of Electrical and Electronics Engineering (IOSR-JEEE) e-ISSN: 2278-1676, p-ISSN: 2320-3331

[16] “ WORKING PHASES OF SCADA SYSTEM FOR POWER DISTRIBUTION NETWORKS" International Journal of Advanced Research in Electrical, Electronics and Instrumentation Engineering, , Vol. 2, Issue 5, May 2013, ISSN (Online): 2278 - 8875

[17] Mazen abd elsalam, Hussein Anis, Ahdab EL- morshedy, Roshdy radwan, "High voltage engineering theory and practice" second edition.

[18] Sungjin Lee, Donghyun Choi, Choonsik Park, and Seungjoo Kim " An Efficient Key Management Scheme for Secure SCADA Communication" World Academy of Science, Engineering and Technology International Journal of Computer, Electrical, Automation, Control and Information Engineering Vol:2, No:9, 2008 Publication $/ 15268$

[19] Ming-Ta Yang, Jyh-Cherng Gu, Po-Chun Lin, Yen-Lin Huang, Chun-Wei Huang, and Jin-Lung Guan "Interoperability and Performance Analysis of IEC61850 Based Substation Protection System” World Academy of Science, Engineering and Technology International Journal of Computer, Electrical, Automation, Control and Information Engineering Vol:7, No:8, 2013 Publication/ 16110 